\title{
Lineament Tectonics and Mineralizatin in Tarom Area, North Iran
}

\author{
Mehran Arian1, Reza Nouri2 \\ ${ }^{1}$ Department of Geology, Science and Research Branch, Islamic Azad University, Tehran, Iran \\ ${ }^{2}$ Young Researchers and Elites Club, North Tehran Branch, Islamic Azad University, Tehran, Iran \\ Email: mehranarian@yahoo.com
}

Received 10 February 2015; accepted 7 March 2015; published 12 March 2015

Copyright (C) 2015 by authors and Scientific Research Publishing Inc.

This work is licensed under the Creative Commons Attribution International License (CC BY). http://creativecommons.org/licenses/by/4.0/

(c) (i) Open Access

\begin{abstract}
The study area that is part of Tarom volcano-plutonic zone which host many hydrothermal base metal deposits located in Zanjan, NW Iran. Understanding the tectonic events that can cause mineralization and hydrothermal alteration are significant factor in assessing the exploration potential of different structures. In this research, hydrothermal alteration such as Iron oxide, argillic, phyllic, and propylitic zones were determined by Spectral Angle Method (SAM) and also lineaments identified by high pass filters and hill-shade DEM techniques on Advanced Space borne Thermal Emission and Reflection Radiometer (ASTER) data. Field studies revealed most alteration and mineralization occurred in NE-SW fractures and control mineralization.
\end{abstract}

\section{Keywords}

Lineament, Alteration, Hydrothermal, Tarom, Iran

\section{Introduction}

The use of satellite images for mineral exploration has been very successful in pointing out the presence of minerals such as alunite, pyrophyllite, kaolinite, sericite, illite, muscovite, smectite, and carbonate which are important in the identification of hydrothermal alterations [1]. In addition, satellite remote sensing provides synoptic view, which is helpful in identification and delineation of various land forms, linear features and structural elements [2] [3]. Hence, in primary stages, mapping geologic lineaments is important for mineral exploration, because of their potentials for harboring ore bodies that are carried and deposited by ascending hydrothermal fluids [4] [5]. Iran is located in the Alpine-Himalayan orogenic and metalogenic belt and has high potentials for gold and copper and other base metal deposits. Satellite images have been used by many Iranian geologist researchers as cheapest method for interpretation of the structural features and exploration purposes [6] [7]. The aim of the 
present study is tectonic control on distribution of hydrothermal alteration zones and mineralization in Tarom Area Based on Remote Sensing Data, NW Iran.

\section{Materials and Methods}

\subsection{Geologic Setting}

Tarom area (Figure 1) is located between longitudes 48 $52^{\prime} 30^{\prime \prime} \mathrm{E}-49^{\circ} 00^{\prime} 00^{\prime \prime} \mathrm{E}$ and latitudes $36^{\circ} 41^{\prime} 28^{\prime \prime} \mathrm{N}$ $36^{\circ} 49^{\prime} 00^{\prime \prime} \mathrm{N}$ in the eastern Zanjan Province, NW Iran.

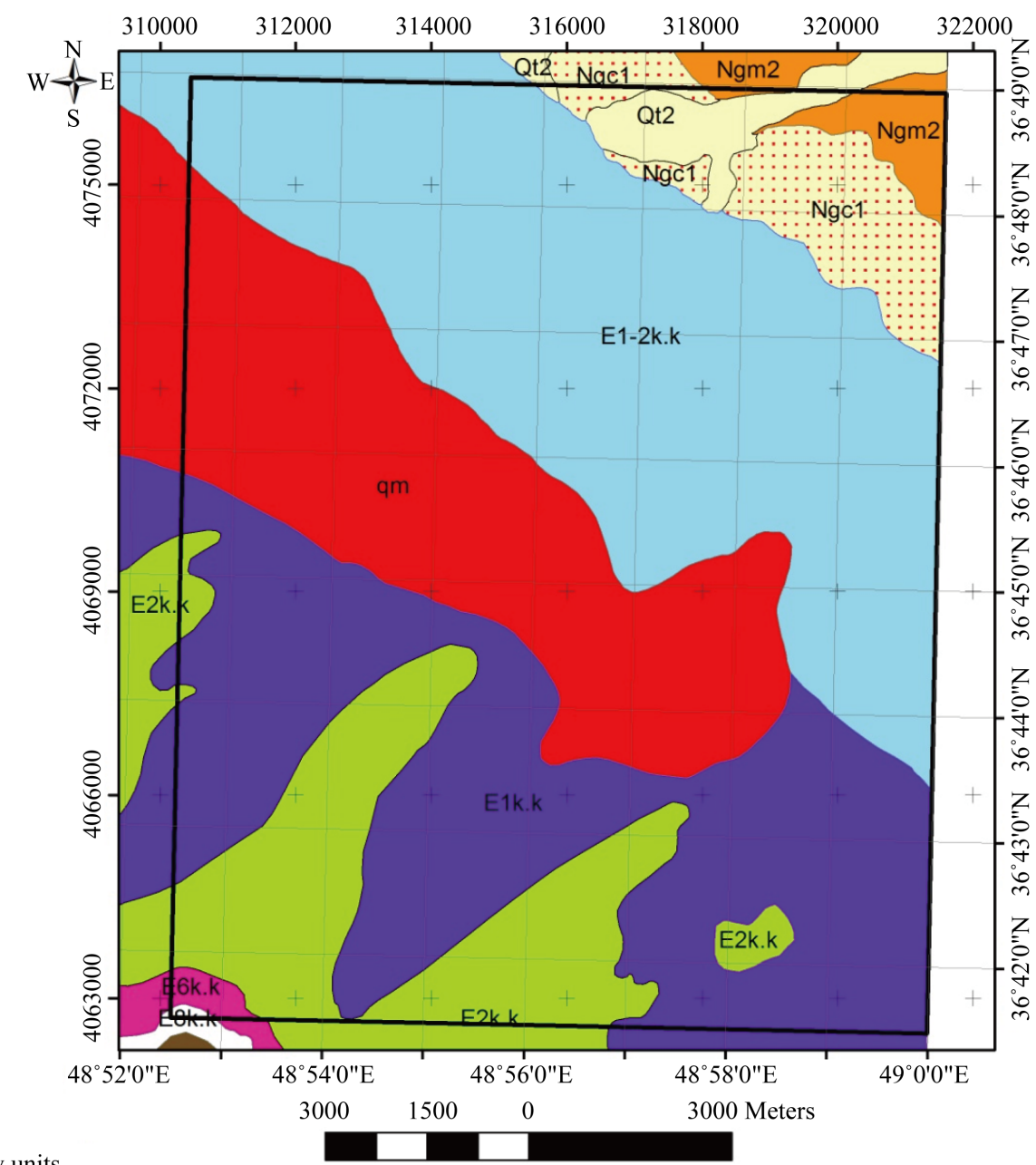

Geology units

E1-2k.k, Greenish gray tuffaceous sandstone, tuff, mudstone, siltston partly with andesitic lava flows.

E1k.k, Greenish gray tuffaceous sandstone, tuff, mudstone.

E2k.k, Tuff, tuffaceous sandstone, siltstone, mudstone with intercalation of tuff.

E3k.a, Sandstone with intercalated mudstone.

E6k.k, Light green to pink tuff breccia, lapilli tuff, pumice tuff, welded tuff, crystal lithic tuff.

$\therefore::::$ Ngc1, Red conglomerate.

Ngm2, Alternation of light green gypsiferous marl, gypsum with reddish gray clay, sandstone and conglomerate.

Qt2, Young terraces.

qm, Quartz monozodiorite - quartz monzonite, quartz syenite.

Figure 1. Geological map of studied area based on 1:100,000 geological map of Tarom. This area has shown in Figure 2 by a black rectangle. 
This area belongs to West-Central Alborz and lesser Caucasus hinterland [8] [9] that formed on the inverted back arc intra-continental rift since Oligocene. Dominant structural trend in West-Central Alborz and lesser Caucasus province is NW-SE (Figure 2). From tectonics view, it contains deformed zone (fold and thrust belt) of Cimmerian miniplate that formed in northern active margin until late Triassic. Then it has rifted by tension in a back arc basin of Neotethyian subduction zone in the south margin of Cimmerian miniplate. Development of that rift stopped in the late Cretaceous and then, renewed in the Eocene by spreading in submarine arc basin of Neotethyian subduction zone. In the other word, this hinterland is result of a magmatic arc system spreading in the evolutional back arc basin. After that, this region has converted to back arc regim again and West-Central Alborz and lesser Caucasus hinterland has formed by its deformation and regional uplift from SW part of Caspian Sea to Black sea. Recently, Damavand and Sebalan cones have formed by late volcanism that related to final subduction of oceanic slab (Neotethys) toward north and northeast [10].

This area has an active tectonics regim [11]-[24] in compared to the Central Iran [25]-[33], Zagros in the southern Iran [34]-[40] and salt diapiric areas in Iran [41] [42]. Also, some consept of its metal mineralization, have investigated by [43]-[46]. Tarom volcanic rocks are changing from rhyodacite, dacite to basalt. Lava rocks such as tuff and tuffite, andesite-basalt, andesite, trachyte, latite, trachyandesitic, dacite, rhyodacite, ignimbrite and moderate acidic tuff volcanic rocks in the Tarom zone have been observed. Also, in the Tarom zone, sericite,

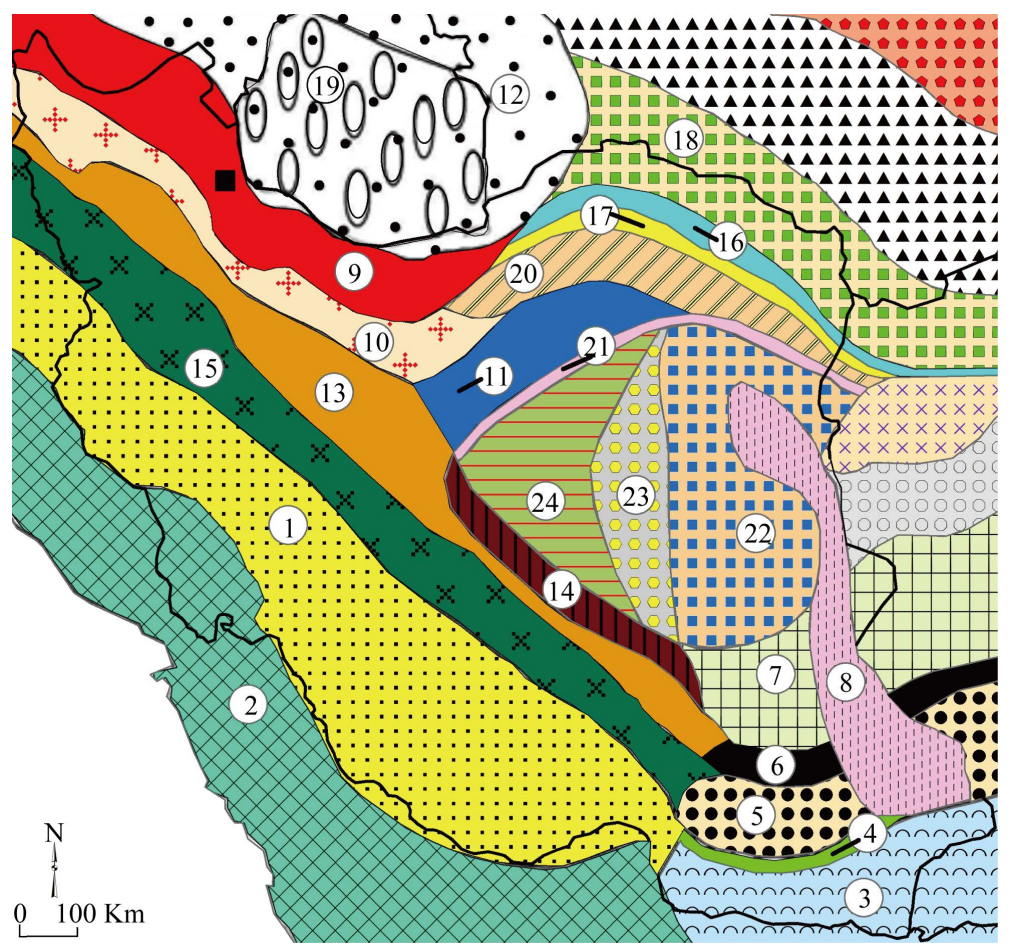

Figure 2. Physiographic-tectonic zoning map of Iran's sedimentary basins Iran, modified from [10]. Numbers in this figure are, 1: Zagros-East Taurus hinterland, 2: Persian Gulf-Mesopotamian foreland basin, 3: Makran accretionary prism, 4: Bashagard Mountains, 5: Jazmorian-Mashkel fore arc basin, 6: Shahsavaran-Soltan magmatic arc, 7: South Lut-South Helmand back arc basin, 8: East Iran Mountain belt, 9: West-Central Alborz and lesser Caucasus hinterland, 10: Great Kavir-Northen Urmieh lake foreland basin, 11: South Great Kavirfold and thrust belt, 12: South Caspian-Black sea foreland basin, 13: Urmieh-Dokhtar Magmatic Arc, 14: Naien-Kerman retro arc foreland basin, 15: Sanandaj-Sirjanoverthrust belts, 16: East Alborz or Binalod hinterland, 17: Torbat-e am-Neyshabour retro arc foreland basin, 18: KopetDagh hinterland, 19: South Caspian remnant basin, 20: Maiamay-Taibad Inverted back arc basin, 21: Khaf-Kavir Plain Magmatic Arc, 22: Lut Plain-Gonabad back arc basin, 23: Tabas hinterland, 24: Yazd-Khour Piggy back basin. The study area is shown in the black rectangle. 
propylitic, silica, chlorite, alunitic, zeolite alteration zones have been identified. Zanjan province has a particular mineral resource position among the structural domains of Iran. All kinds of metamorphic basement rocks, ophiolites (ancient oceanic lithosphere), and magmatic arcs can be observed in this province.

As a result, various types of mineral resources exist in this territory, which have made this province a highpotential mineral resource domain in Iran [47]. Based on 1:100,000 geological map of Tarom, the most impressive geological feature in studied area is the Eocene sequences which composite of quartz-monzonite that spread northwest to southeast of investigated area. Sandstone, tuffaceous sandstone, and andesite lava flows formed other part of studied area. The conglomerate, gypsiferous marl and young terraces are in the north west of investigated area [48].

\subsection{ASTER Data}

The ASTER is an advanced optical sensor comprised of 14 spectral channels ranging from the visible to thermal infrared region. It will provide scientific and also practical data regarding various field related to the study of the earth [49]. Various factors affect the signal measured at the sensor, such as drift of the sensor radiometric calibration, atmospheric and topographical effects. For accurate analysis, all of these corrections are necessary for remote sensing imagery.

To this end, at the beginning of the path, data set AST_L1B_010_8200745110108311331 in hierarchical data format (HDF) was used for this research and radiance correlation such as wavelength, dark subtract and log residual by ENVI4.4 software which is essential for multispectral images, were implemented.

\section{Results and Discussion}

\subsection{Hydrothermal Alteration Detection}

By using of spectral angle mapper method alteration zones were determined. SAM method is a classification technique that permits rapid mapping by calculating the spectral similarity between the image spectrums to reference reflectance spectra. SAM measures the spectral similarity by calculating the angle between the two spectra, treating them as vectors in n-dimensional space [50] [51]. The image spectra were compared with USGS Digital Spectral Library (Minerals) [52]. Figure 3 show selected minerals spectral library plots that related to iron oxide, argillic, phyllic and propylitic alterations.
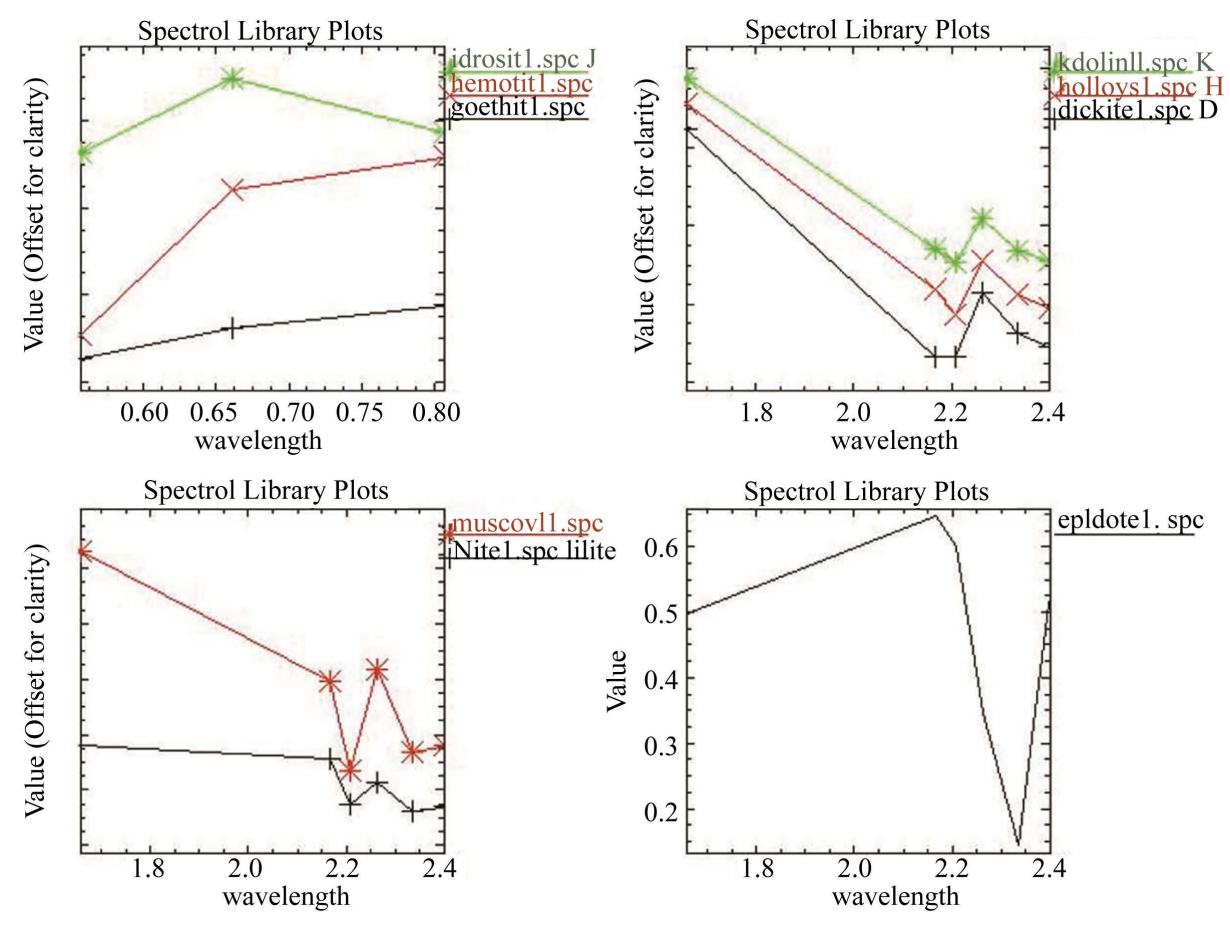

Figure 3. Spectral library plots from USGS library. 
Three mineral spectral representative of iron oxide include jarosite, hematite, goethite, three mineral spectral representative of argillic zone include kaolinite, dickite and halloysite, three minerals spectral representative of phyllic alteration consist of illite and muscovite and epidote representative of propylitic zone were selected (Figure 4).


Figure 4. The iron oxide, argillic, phyllic, and propylitic images prepared based on SAM method. 


\subsection{Lineament Extraction}

Lineament extraction in this study is performed in Manual method. In manual extraction method, the lineaments are extracted from satellite image by using visual interpretation. The lineaments usually appear as straight lines or "edges" on the satellite images which in all cases contributed by the tonal differences within the surface material. The knowledge and the experience of the user is the key point in the identification of the lineaments particularly to connect broken segments into a longer lineament [53].

False color images are produced for manual lineament extraction because they increase the interpretability of the data. Different combinations of three bands are examined and the best visual quality is obtained with a false color image utilizing three 7, 4, and 2 (in blue, green and red respectively).

This false color combination made it easier to identify linear patterns of vegetation, geologic formation boundaries, river channels, geological weakness zones. Moreover, filtering operations are used to emphasize or deemphasize spatial frequency in the image. The filtering operation will sharpen the boundary that exists between adjacent units. Furthermore, standard GIS techniques have been carried out to help in the evaluation of the lineaments detected. Digital Elevation Model (DEM) has the advantage of representing the vertical extension of the earth's surface by assigning height values for every pixel [54].

Also, hill-shade DEM technique is effective in creating images that enhance geomorphologic features. Therefore, Hill-shades DEM with different azimuth direction and sun angle were used in this study (Figure 5). Integration of alteration and lineament with accordance to geology map of studied area is shown in Figure 6.

\section{Ground-Truth Verification}

To evaluate the ASTER satellite data, discriminate alteration zones and lineaments, field-checks have been verified. In almost all cases, our fieldwork confirmed in showing real alteration and detection of area of lineament by the interpreted remote sensing imagery. The field photographs of the hydrothermally altered rocks are shown in Figure 7. Microscopic photographs of the study areas are shown in Figure 8.

\section{Conclusion}

The use of remote sensing data in the early stages of mineral exploration was very successful for recognition of
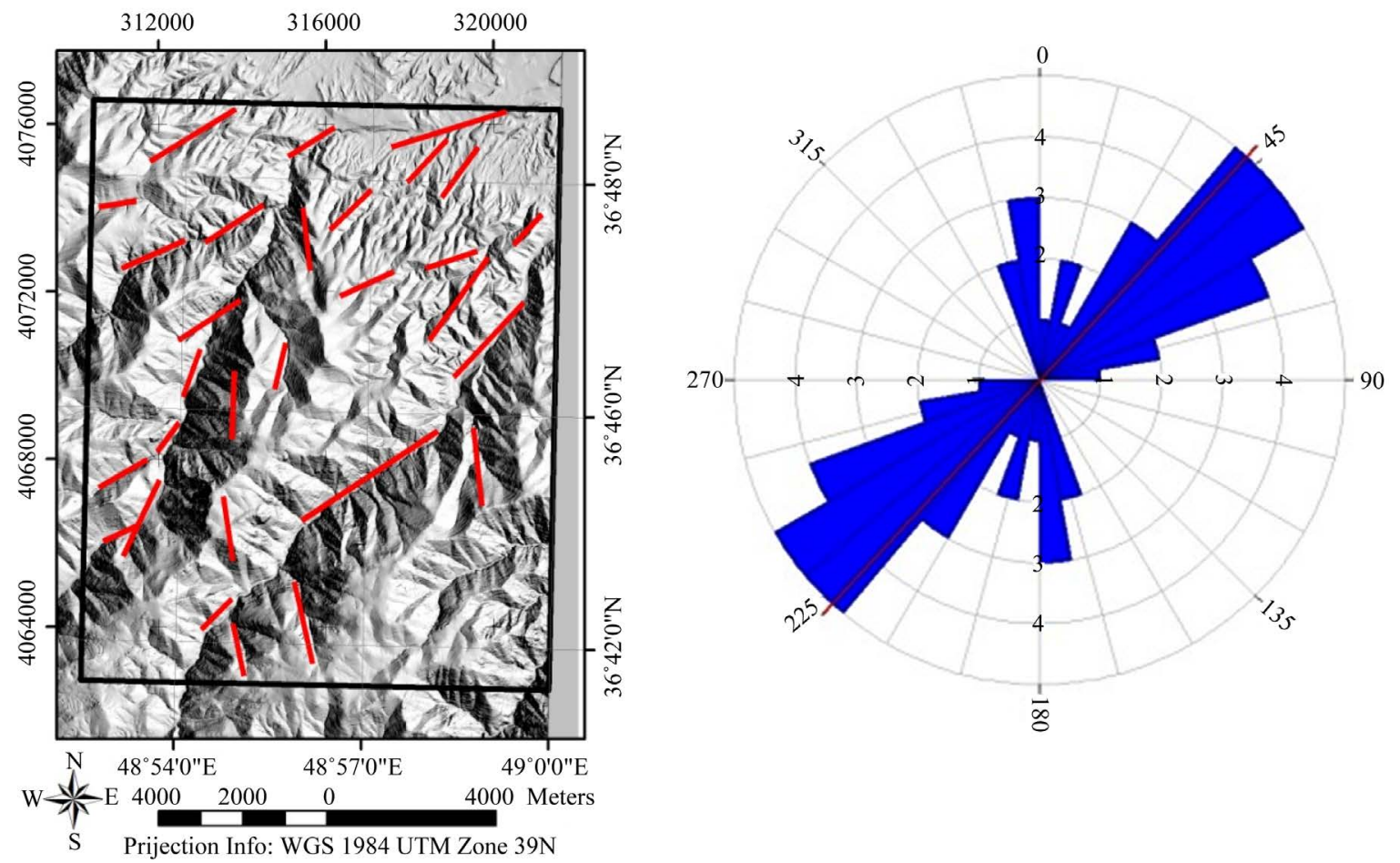

Figure 5. Lineament and rose diagram of studied area. 


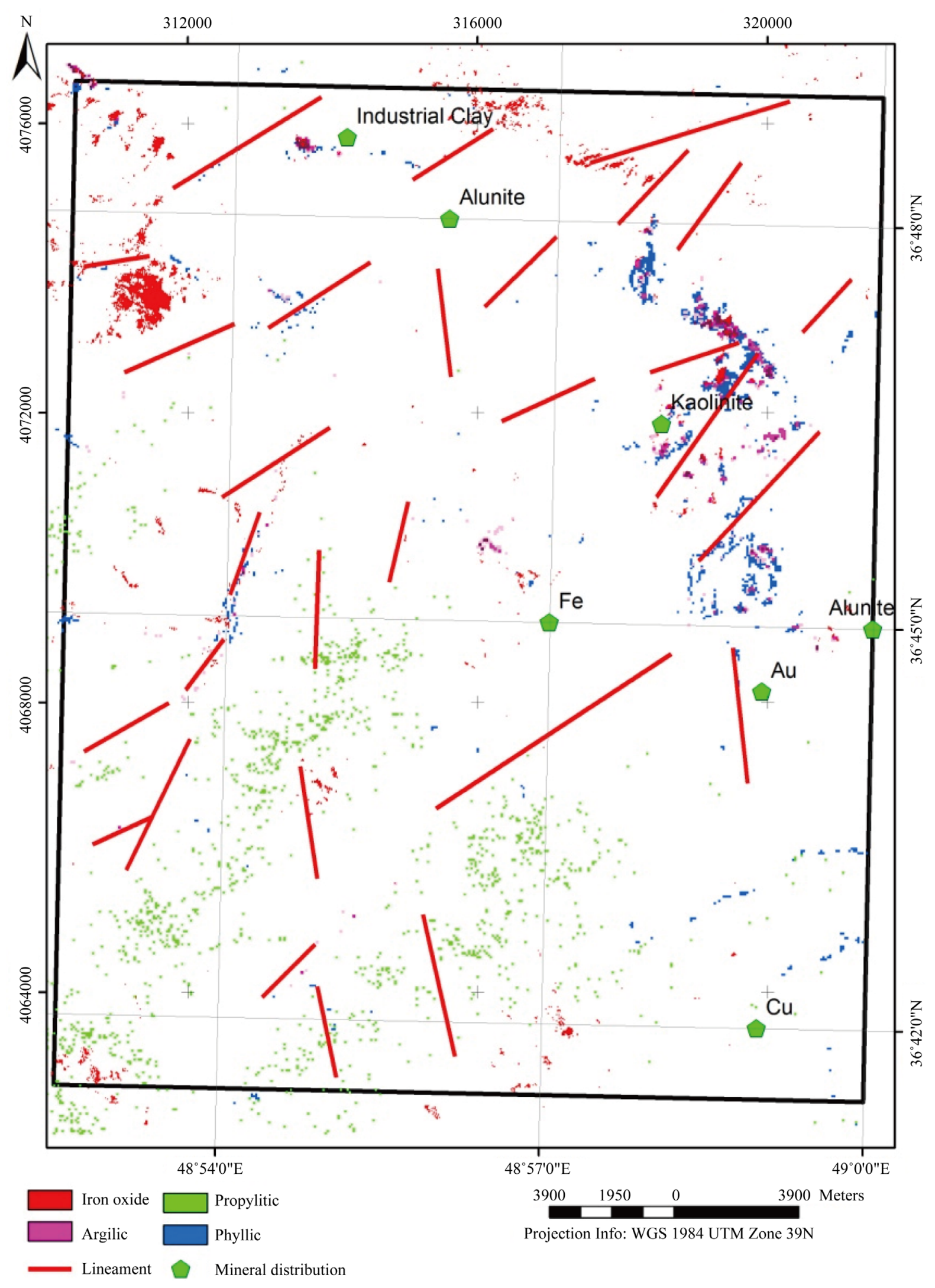

Figure 6. Integration of alteration and lineament. 

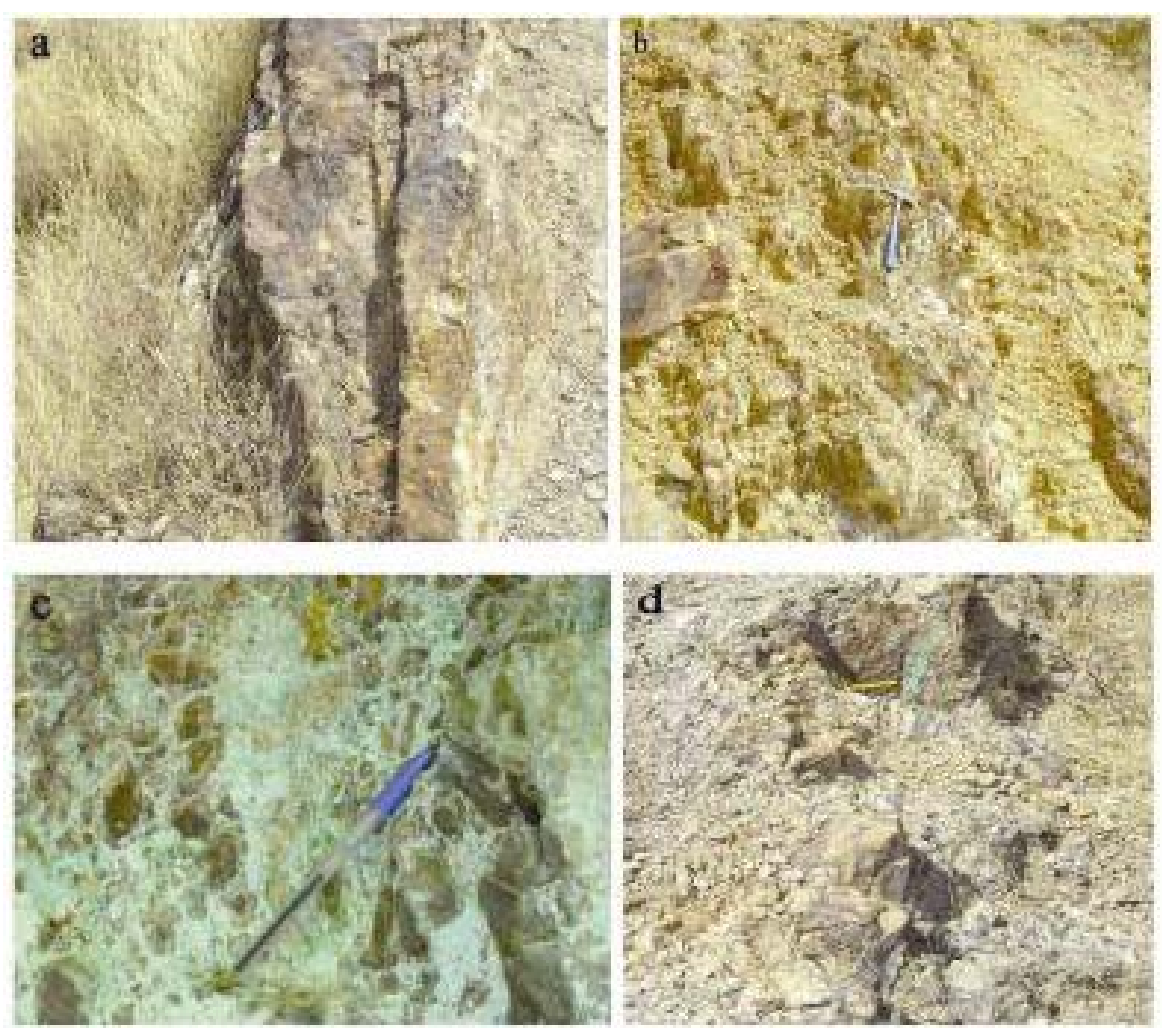

Figure 7. Field photographs of the study area. (a) View of the iron oxide; (b) View of the silica vein- and argillic-altered rocks (c) View of the propylitic-altered rocks; (d) View of the copper and gold outcrop.
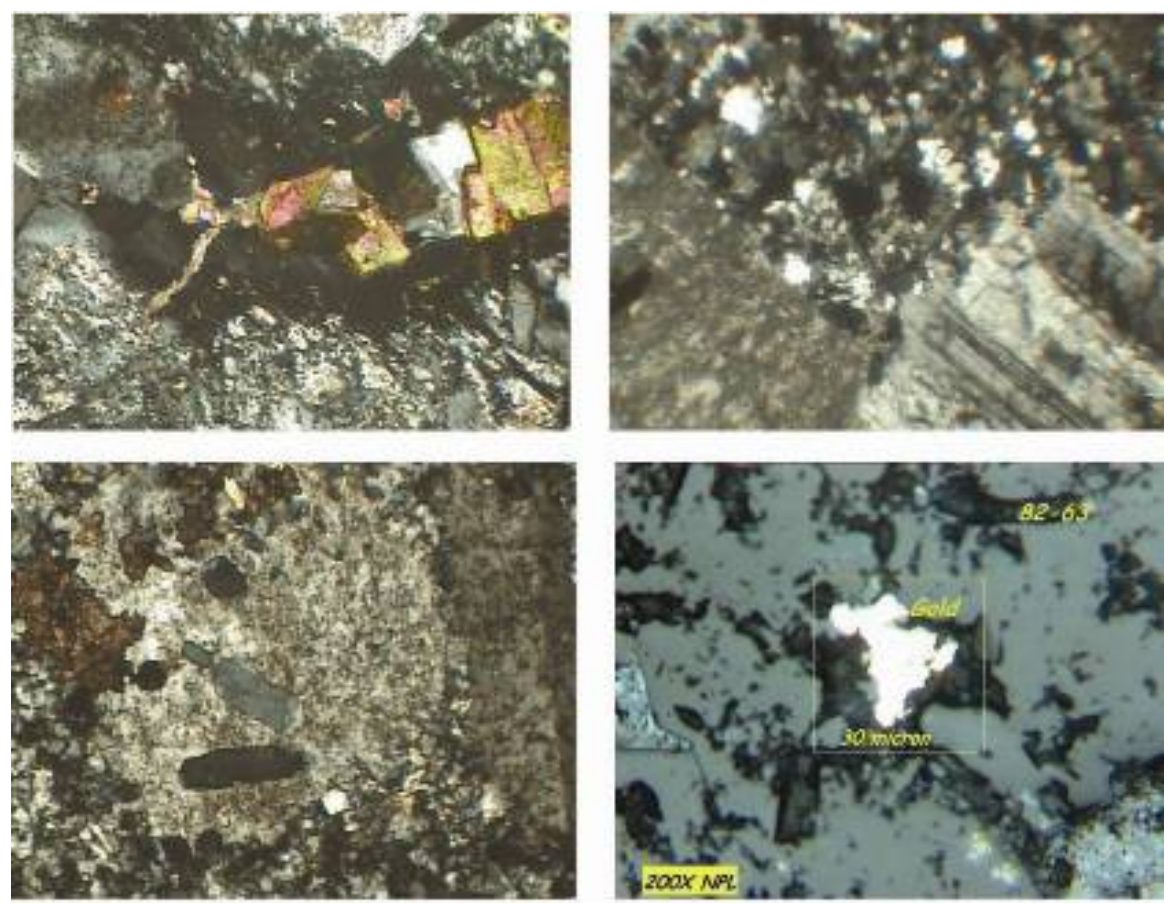

Figure 8. Microscopic photographs of the study areas. (a) Thin section of quartzmonzonite with clay minerals, 40 XPL; (b) Thin section of granite with sericite and iron oxide, 40 XPL; (c) Thin section of monzodiorite with chlorite, 40 XPL; (d) Gold in silica gangue. 
the hydrothermal alterations. Moreover, ASTER multi spectral images could be used for the identification of lineaments possibly related to faults. The performance of conventional image processing techniques has been evaluated on ASTER bands. Results show that the integration of the image processing techniques has great ability to detect iron oxide, argillic, phyllic and propylitic. Field checks also confirmed in showing real alteration and detection of area of lineament by the interpreted remote sensing imagery.

\section{Acknowledgements}

This work has funded by the Department of geology, Islamic Azad University, Science and Research branch, Tehran, Iran. Also, Special thanks to vice-president for research in Science and Research branch, Tehran. The authors are grateful to Shahram Rahmani, Exploration Department of Geological Survey of Iran for his sincere help and valuable discussions especially in field checks and interpretation of microscopic sections.

\section{References}

[1] Salem, S.M., Arafa, S.A., Ramadan, T.M. and El Gammal, E.S.A. (2011) Exploration of Copper Deposits in Wadi El Regeita Area, Southern Sinai, Egypt, with Contribution of Remote Sensing and Geophysical Data. Arabian Journal Geoscience, 6, 321-335. http://dx.doi.org/10.1007/s12517-011-0346-z

[2] Javed, A. and Wani, M.H. (2009) Delineation of Groundwater Potential Zones in Kahund Watershed, Eastern Rajasthan, Using Remote Sensing and GIS Techniques. Journal of the Geological Society of India, 73, 229-236. http://dx.doi.org/10.1007/s12594-009-0079-8

[3] Adham, M.I., Jahan, C.S., Mazumder, Q.H., Hossain, M.M.A. and Haque, A.L. (2010) Study on Groundwater Recharge Potentiality of Barind Tract, Rajshahi District, Bangladesh Using GIS and Remote Sensing Technique. Journal of the Geological Society of India, 75, 432-438. http://dx.doi.org/10.1007/s12594-010-0039-3

[4] Kujjo, C.P. (2010) Application of Remote Sensing for Gold Exploration in the Nuba Montains, Sudan. Master of Science Thesis, Bowling Green State University, Bowling Green.

[5] Green, A.A., Berman, M., Switzer, P. and Craig, M.D. (1988) A Transformation for Ordering Multispectral Data in Terms of Image Quality with Implications for Noise Removal. IEEE Transactions on Geoscience and Remote Sensing, 26, 65-74. http://dx.doi.org/10.1109/36.3001

[6] Asadi Haroni, H. and Lavafan, A. (2007) Integrated Analysis of ASTER and Landsat ETM Data to Map Exploration Targets in the Muteh Gold-Mining Area, Iran. 5th International Symposium on Spatial Data Quality, Enschede, 13-15 June 2007, 4 p.

[7] Azizi, H., Tarverdi, M.A. and Akbarpour, A. (2010) Extraction of Hydrothermal Alterations from ASTER SWIR Data from East Zanjan, Northern Iran. Advances in Space Research, 46, 99-109. http://dx.doi.org/10.1016/j.asr.2010.03.014

[8] Qorashi, M. and Arian, M. (2011) Tectonics of Iran. Geological Survey of Iran, 336 p. (In Persian)

[9] Arian, M. (2011) Basement Tectonics and Geology of Iran. Asar Nafis Press, Qum, 300 p. (In Persian)

[10] Arian, M. (2013) Physiographic-Tectonic Zoning of Iran’s Sedimentary Basins. Open Journal of Geology, 3, 169-177. http://dx.doi.org/10.4236/ojg.2013.33020

[11] Arian M., Maleki Z. and Noroozpour H. (2011) Cenozoic Diastrophism and Deformational Events in the East-Central Alborz. Journal of Basic and Applied Scientific Research, 1, 2394-2400.

[12] Feizi, F., Arian, A. and Rahmani, R. (2007) Seismotectonic Zoning in the Eastern Part of the Central Alborz. Journal of Sciences, 17, 151-164. (In Persian)

[13] Khavari, R., Arian, M. and Ghorashi, M. (2009) Neotectonics of the South Central Alborz Drainage Basin, in NW Tehran, N Iran. Journal of Applied Sciences, 9, 4115-4126. http://dx.doi.org/10.3923/jas.2009.4115.4126

[14] Arian, M. and Bagha, N. (2012) Active Tectonics of Tehran Area, Iran. Journal of Basic and Applied Scientific Research, 2, 3805-3819.

[15] Bagha, N., Arian, M., Ghorashi, M., Pourkermani, M., El Hamdouni, R. and Solgi, A. (2014) Evaluation of Relative Tectonic Activity in the Tehran Basin, Central Alborz, Northern Iran. Geomorphology, 213, 66-87. http://dx.doi.org/10.1016/j.geomorph.2013.12.041

[16] Arian, M. and Feizi, F. (2005) Application of Geomorphic Indices to the Assessment of Relative Tectonic Activity Levels in The Alborz-Central Iran Border Zone (from the East of Varamin to the East of Semnan). Journal of Sciences, 15, 378-403.

[17] Arian, M. and Pourkermani, M. (2004) Tectonic Elements of South Flank in the East-Central Alborz Mountain. Journal of Sciences, 4, 359-368. 
[18] Arian, M. and Qorashi, M. (2006) The Movement Potential Evaluation of the Major Quaternary Faults in Alborz-Central Iran Border Zone, from the East of Tehran to the East of Semnan. Journal of Geosciences, 15, 184-188.

[19] Poroohan, N., Pour Kermani, M. and Arian, M. (2013) An Assessment of Relationship in F-Parameter and Paleostress Fields in Heterogeneous Lithologies: Roudbar Area (Northwest of Iran). Australian Journal of Basic \& Applied Sciences, 7, 933-942.

[20] Poroohan, N., Kermani, M.P. and Aryan, M. (2009) An Assessment on Correlations of Seismotectonic Parameters Preceding and Following Roudbar-Manjil Earthquake (Gilan, North of Iran). Australian Journal of Basic \& Applied Sciences, 3, 2643-2652.

[21] Pourkermani M. and Arian M. (2001) Structural Geomorphology of Northeastern Kurdistan, Sistan and Baluchestan University. Journal of Humanities, 7, 37-48.

[22] Mardani, Z., Ghorashi, M. and Arian, M. (2011) Geomorphic Signatures of Active Tectonics in the Talaghan Rud, Shah Rud and Sefidrud Drainage Basins in Central Alborz, N Iran. Geosciences, 20, 159-166.

[23] Sorbi, A., Arian, M. and Pourkermani, M. (2011) The Application of Geomorphic Indices to the Assessment of Relative Tectonic Activity Levels in Tehran Quadrangle. Journal of the Earth, 6.

[24] Khavari, R., Ghorashi, M., Arian, M. and Khosrotehrani, K. (2010) Geomorphic Signatures of Active Tectonics in the Karaj Drainage Basin in South Central Alborz, N Iran. Geosciences, 19, 67-74.

[25] Arian, M., Toudeshki, V.H. and Noroozpour, H. (2011) Active Tectonics of Qezel Ozan River Basin, NW Iran. Journal of Applied Environmental and Biological Sciences, 1, 291-295.

[26] Housini Toudeshki, V., Pourkermani, M., Arian, M. and Khosrotehrani, K.H. (2011) Influence of Structures on the Ghezel Ozan River. Geosciences, 21, 55-60.

[27] Housini Toudeshki, V. and Arian, M. (2011) Morphotectonic Analysis in the Ghezel Ozan River Basin, NW Iran. Journal of Geography and Geology, 3, 258-260.

[28] Arian, M. (2012) Clustering of Diapiric Provinces in the Central Iran Basin. Carbonates and Evaporites, 27, 9-18. http://dx.doi.org/10.1007/s13146-011-0079-9

[29] Pourkermani, M. and Arian, M. (1997) Salt Domes of Central Iran. Journal of Humanities University of Sistan and Balouchestan, 3, 29-41. (In Persian)

[30] Arian, M., Pourkermani, M., Sistanipour, A. and Noroozpour, H. (2011) Kinematic Significance of Fold- and FaultRelated Fracture Systems in the Rafsanjan’s Northeast Highlands (Central Iran). Journal of Basic and Applied Scientific Research, 1, 3398-3406.

[31] Arian, M., Pourkermani, M., Sistanipour, A. and Noroozpour, H. (2011) Seismicity and Fault Segmentation of BafqBaghin Fault System (Central Iran). Journal of Applied Environmental and Biological Sciences, 1, 382-396.

[32] Asadian, F. and Arian, M. (2009) Identification of Diapiric Provinces of Central Iran through Geological and Geographical Analysis. International Journal of Agriculture Environment Biotechnology, 2, 3443-3451.

[33] Arian, M. (2010) Earthquake-Fault Hazard Investigations in the Kerman Quadrangle. Journal of Sciences, 19, 176182. (In Persian)

[34] Arian, M. and Aram, Z (2014) Relative Tectonic Activity Classification in the Kermanshah Area, Western Iran. Solid Earth, 5, 1277-1291. http://dx.doi.org/10.5194/se-5-1277-2014

[35] Mashal, M., Kermani, M.P., Charchi, A., Almasian, M. and Arian, M. (2013) Pattern of Structural Geology Underground in Eastern of North Dezfol Embayment. Advances in Environmental Biology, 7, 260-268.

[36] Pazhoohan, M., Arian, M., Ghorashi, M. and Khosrotehrani, K. (2014) A Study of Drainage Pattern Responses to Active Tectonics in Tadvan Region, SW Iran. Geodynamics, 1, 36-41.

[37] Rahimi, N. and Arian, M. (2014) Tectonic Geomorphplogy of Hamedan-Sosangerd Region, West Iran. Advances in Environmental Biology, 8, 119-124.

[38] Arian, M. and Hashemi, A. (2008) Seismotectonic Zoning in the Zagros. Journal of Sciences, 18, 63-76. (In Persian)

[39] Arian M., Ahmadnia A., Qorashi M. and Pourkermani M. (2002) Structural Analysis of Mengharak Transcurrent Fault System in Zagros, Iran. Special Geo 2002 Conference Issue Geoarabia, 7, 209-210

[40] Arian, M., Qorashi, M., Pourkermani, M. and Ahmadnia, A. (2006) The Structural Significance Kareh Bas Transcurrent Fault System in the Zagros Fold and Thrust Belt. Journal of Geosciences, 15, 126-133. (In Persian)

[41] Arian, M. and Noroozpour, H. (2015) The Biggest Salt-Tongue Canopy of Central Iran. Open Journal of Geology, 5, 55-60. http://dx.doi.org/10.4236/ojg.2015.52005

[42] Arian, M. and Noroozpour, H. (2015) Tectonic Geomorphology of Iran’s Salt Structures. Open Journal of Geology, 5, 61-72. http://dx.doi.org/10.4236/ojg.2015.52006

[43] Nouri, R., Jafari, M.R., Arian, M., Feizi, F. and Afzal, P. (2013) Correlation between Cu Mineralization and Major 
Faults Using Multifractal Modelling in the Tarom Area (NW Iran). Geologica Carpathica, 64, 409-416.

[44] Nouri, R., Jafari, M.R., Arian, M., Feizi, F. and Afzal, P. (2013) Prospection for Copper Mineralization with Contribution of Remote Sensing, Geochemical and Mineralographical Data in Abhar 1:100000 Sheet, NW Iran. Archives of Mining Sciences, 58, 1071-1084.

[45] Nouri, R., Afzal, P., Arian, M., Jafari, M. and Feizi, F. (2013) Reconnaissance of Copper and Gold Mineralization Using Analytical Hierarchy Process (AHP) in the Rudbar 1:100000 Map Sheet, Northwest Iran. Journal of Mining and Metallurgy A: Mining, 49, 9-19.

[46] Feizi, F. and Arian, M. (2011) The Role of Structural Controllers in Geneses of Copper Deposits in 1:50000 Map of Saiin Qaleh. Journal of Sciences, 21, 1-10.

[47] Rahmani, S. (2011) Report of Primary Exploration in the 1:25000 Lohneh-Zardeh Exploration Target (Tarom Exploration Zone, Zanjan Province). Geological Survey of Iran (GSI). (In Persian)

[48] Hirayama, K. and Amini, B. (1966) Geological Map of Tarom. Geological Survey of Iran (GSI).

[49] Watanabe, H. and Matsuo, K. (2003) Rock Type Classification by Multi-Band TIR of ASTER. Geosciences Journal, 7, 347-358. http://dx.doi.org/10.1007/BF02919567

[50] Kruse, F.A., Boardman, J.W., Lefkoff, A.B., Heidebrecht, K.B., Shapiro, A.T., Barloon, P.J. and Goetz, A.F.H. (1993) The Spectral Image Processing System (SIPS) - Interactive Visualization and Analysis of Imaging Spectrometer Data. Remote Sensing of Environment, 44, 145-163.

[51] Pour, A.B. and Hashim, M. (2012) Identifying Areas of High Economic-Potential Copper Mineralization Using ASTER Data in the Urumieh-Dokhtar Volcanic Belt, Iran. Advances in Space Research, 49, 753-769. http://dx.doi.org/10.1016/j.asr.2011.11.028

[52] Malekzadeh, A., Karimpour, M.H., Stern, C.R. and Mazaheri, S.A. (2009) Hydrothermal Alteration Mapping in SW Birjand, Iran, Using the Advanced Spaceborne Thermal Emission and Reflection Radiometer (ASTER) Image Processing. Journal of applied Sciences, 9, 829-842.

[53] Sarp, G. (2005) Lineament Analysis from Satellite Images, North-West of Ankara. Master of Science Dissertation, School of Natural and Applied Science of Middle East Technical University, Ankara.

[54] Papadaki, S.E., Mertikas, S.P. and Sarris, A. (2011) Identification of Lineaments with Possible Structural Origin Using ASTER Images and DEM Derive Products in Western Crete, Greece. European Association of Remote Sensing Laboratories (ARSeL). 